\title{
Influence of Partial Coarse Fraction Substitution of Natural Aggregate by Recycled Concrete Aggregate in Hot Asphalt Mixtures
}

\author{
Debora Acosta Álvarez ${ }^{1}$, Anadelys Alonso Aenlle ${ }^{1}$, Antonio José Tenza-Abril ${ }^{2}$ and \\ Salvador Ivorra ${ }^{2, *(1)}$ \\ 1 Faculty of Civil Engineering, Technological University of Havana "José Antonio Echeverría", \\ Havana 11500, Cuba; dacostaa@civil.cujae.edu.cu (D.A.Á.); anadelys@civil.cujae.edu.cu (A.A.A.) \\ 2 Department of Civil Engineering, University of Alicante, 03080 Alicante, Spain; ajt.abril@ua.es \\ * Correspondence: sivorra@ua.es; Tel.: +34-96-5903-400 (ext. 9410)
}

Received: 27 November 2019; Accepted: 25 December 2019; Published: 27 December 2019

\begin{abstract}
The main objective of this work is to evaluate the properties of hot asphalt mixtures that have been manufactured with different recycled concrete aggregate (RCA) percentages $(0 \%, 20 \%, 40 \%, 60 \%$ and $80 \%$ of the fraction $5-13 \mathrm{~mm}$ ) and asphalt $(4 \%, 4.5 \%$ and $5 \%)$. Dense asphalt mixtures were made; partially replacing the natural aggregate (NA) fraction between 5 and $13 \mathrm{~mm}$. Marshall specimens were manufactured to determine the main properties of the asphalt concrete $(\mathrm{AC})$ in terms of density, voids, stability and deformation. Additionally, the optimal asphalt content (OAC) was determined, and measured the water sensibility, the stiffness modulus and the permanent deformation. The results corroborate the potential for using these sources of construction and demolition waste (CDW) as a RCA in asphalt concrete and show that the hot asphalt mixtures with up to $40 \%$ substitution of natural aggregate by recycled aggregate in the fraction $5-13 \mathrm{~mm}$ present good behavior.
\end{abstract}

Keywords: recycled concrete aggregates (RCA); construction and demolition waste (CDW); hot asphalt mixtures

\section{Introduction}

Currently, due to the constant evolution in construction, tons of solid waste are generated resulting from new construction, remodeling, or the demolition of structures [1,2]. The global impacts of solid waste are growing fast. The indiscriminate use of non-renewable natural resources generates waste without adequate final disposal causing enormous impacts on health, environment and economy. The use of wastes in asphalt mixtures to enhance the performance of asphalt concrete pavement is not a new technique [3]. The quantities of waste materials are growing. The lack of natural resources and the shortage of landfill spaces [4] represent the importance of finding innovative ways of reusing and recycling waste materials [5]. To preserve the environment, conserve natural resources, reduce costs and make rational use of energy, several countries are managing the recycling and reuse of construction and demolition waste (CDW) [6,7].

Road construction is an activity in which natural resources are utilized the most in comparison with other branches of civil engineering. In the manufacture of asphalt mixtures, large quantities of natural aggregates (NA) are consumed. These mainly come from quarrying, causing serious environmental effects, as well as significant economic and energy costs.

Consequently, new techniques and research have developed to use the CDW as a NA replacement [8-20]. Great advantages are obtained from the use of CDW as a partial or total replacement of NA. Pavement construction is a potential field for reusing waste promoting the 
reduction of environmental impacts associated with quarrying and transporting aggregates and reducing the accumulation in landfills.

The use of CDW in hot mix asphalt has been widely studied in both their manufacture and its influence in their behavior [21-30]. CDW constitutes a major portion of total solid waste production and it can cover a very wide range of materials. Recycled concrete aggregates (RCA) are aggregates obtained by recycling clean concrete waste where the content of other wastes must be very low. Studies carried out $[24,31,32]$ have shown that the density of mixtures with RCA from CDW decreases due to the mortar adhered to its surface as a result of the CDW crushing.

The effectiveness of RCA varies greatly, as does its composition, depending on: (i) the source of production; (ii) the production process; and iii) the original aggregate characteristics [27,33]. Therefore, the properties of asphalt mixtures manufactured also vary depending on the RCA used.

Some authors $[34,35]$ found that the RCA incorporation into mixtures entails an increase of their stability. However, others investigators $[27,36]$ have shown that the stability of the mixtures can decrease depending on the RCA.

Fatemi [30] showed a reduction in the indirect tensile strength (in dry and wet states) in asphalt mixtures with RCA compared with conventional asphalt mixtures. The opposite can be seen in studies carried out by Pérez [36].

Other authors $[37,38]$ who have investigated the use of CDW in mixtures have achieved results where the stiffness modulus increases with the RCA incorporation in asphalt mixtures, as opposed to the study carried out by Paranavithana [24].

A high number of researchers have the criterion of increasing the optimal asphalt content (OAC) with the use of RCA in asphalt mixtures [22,24,26,32,37]. The mortar adhered to the NA [39,40] is more porous and less dense than the original aggregate, and seems to be responsible for the loss of RCA quality $[22,24,36]$.

There are many different approaches and results to which researchers have arrived when RCA is incorporated to asphalt mixtures, so this work aims to analyze the properties of hot mix asphalt with RCA for the conditions of Cuba, due to the use of this material being a new technique for Cuban pavement and the government's priority goal. The determination of OAC and properties such as density, percentage of voids, stability, deformation, sensitivity to water, stiffness modulus and permanent deformation are analyzed for asphalt mixtures with RCA. A partial substitution of NA $5-13 \mathrm{~mm}$ fractions by RCA at $20 \%, 40 \%, 60 \%$ and $80 \%$ levels.

\section{Materials and Methods}

\subsection{Materials}

Four fractions of limestone NA $(<0.074 \mathrm{~mm}, 0-5,5-13$ and $13-25 \mathrm{~mm})$ and RCA from the demolition and crushing of concrete waste were used for developing the asphalt mixture designs-both supplied by the company Holcim Morteros S.A. (Figure 1). The aggregate supplier certifies the following percentages of impurities present in the RCA: (i) clays $<5 \%$; (ii) lightweight particles $<1 \%$; (iii) asphalt $<1 \%$; and, (iv) other impurities $<1 \%$.

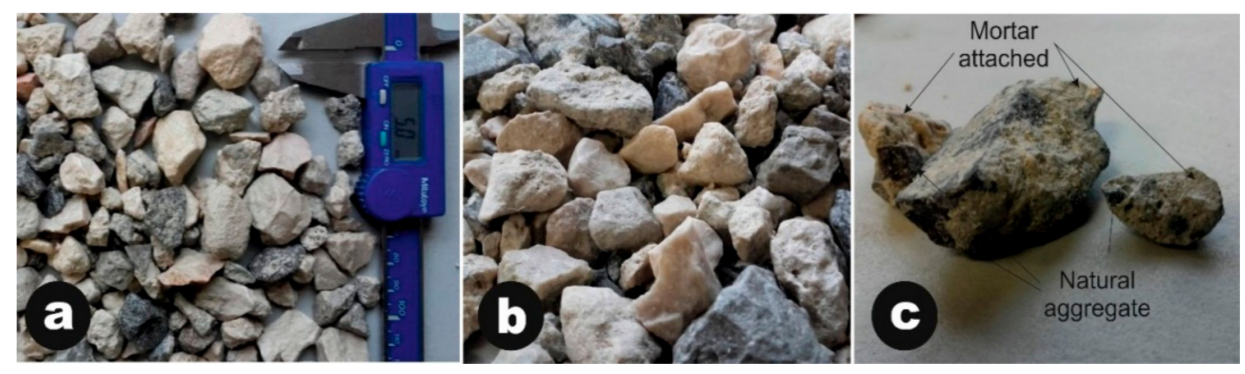

Figure 1. (a) and (b) Recycled aggregate from the construction and demolition used in this research; (c) detail of the attached mortar to the natural aggregate. 
Table 1 shows the main properties of the NA and RCA used to manufacture asphalt concrete (AC). The values are the average of three tests. The apparent densities and water absorption after 24 hours were obtained according to the European standard UNE-EN 1097-6 [41], the values of the Angeles coefficient for coarse aggregates obtained by means of UNE-EN 1097-2 [42], the flakiness index according to UNE-EN 933-3 [43], and assessment of fines according to UNE-EN 933-8 [44].

Table 1. Properties of the aggregates used for designing the asphalt concrete (AC).

\begin{tabular}{|c|c|c|c|c|c|c|}
\hline \multirow[t]{2}{*}{ Properties } & \multicolumn{4}{|c|}{ Natural Aggregate (NA) Fraction } & \multirow{2}{*}{$\begin{array}{c}\text { Recycled Concrete } \\
\text { Aggregates (RCA) }\end{array}$} & \multirow[t]{2}{*}{ Requirements } \\
\hline & $13-25 \mathrm{~mm}$ & 5-13 mm & $0-5 \mathrm{~mm}$ & $<0.074 \mathrm{~mm}$ & & \\
\hline Apparent density $\left(\mathrm{kg} / \mathrm{m}^{3}\right)$ & 2699 & 2669 & 2691 & 2640 & 2372 & $>2500$ \\
\hline 24-h water absorption (\%) & 0.704 & 1.099 & 1.952 & & 4.487 & $0.8-2.5$ \\
\hline Angeles coefficient (\%) & 21.82 & 24.69 & & & 30.00 & $\leq 30$ \\
\hline Flakiness index (\%) & 9.10 & 4.48 & & & 3.20 & $<10$ \\
\hline Sand equivalent (\%) & & & 72.07 & & & $>50 \%$ \\
\hline
\end{tabular}

As can be observed in Table 1, the apparent density of RCA is lower and the 24-h absorption is higher than NA due to the attached mortar, and does not meet with the Cuban standard requirements. The mortar attached is lighter than the original aggregate causing the lower RCA density [45]. The high value of Angeles coefficient is also attributed to the mortar adhered to the original aggregate. When the RCA is subjected to abrasive loading, it fragments easily causing greater wear [33].

Table 2 lists the properties of the asphalt used and the standard used. The requirements established in the European standards UNE EN 12591 [46] of the asphalt are also included in Table 2.

Table 2. Properties of the asphalt used in the mixtures design.

\begin{tabular}{cccc}
\hline Properties & Standard & Value & Requirements \\
\hline Penetration grade $(1 / 10 \mathrm{~mm})$ & UNE-EN 1426 [47] & 52.28 & $50-70$ \\
Softening Point $\left({ }^{\circ} \mathrm{C}\right)$. & UNE-EN 1427 [48] & 52 & $46-54$ \\
\hline
\end{tabular}

The asphalt used in this research is classified as B50/70 according to the Spanish Technical Specifications (PG-3) [49]. As indicated in Table 2, the values of the properties analyzed comply with the quality indices.

\section{Asphalt Mixtures Design}

In this research, five dense mixtures with a maximum size of $25 \mathrm{~mm}$ were made following the Marshall Method set out in NC 261 [50].

- $\quad$ Mixture 1 ( $0 \%$ RCA): Conventional asphalt mixture without RCA.

- Mixture 2 (20\% RCA): Asphalt mixture replacing $20 \%$ of $5-13 \mathrm{~mm}$ fraction of NA by RCA.

- Mixture 3 (40\% RCA): Asphalt mixture replacing $40 \%$ of $5-13 \mathrm{~mm}$ fraction of NA by RCA.

- Mixture 4 (60\% RCA): Asphalt mixture replacing $60 \%$ of $5-13 \mathrm{~mm}$ fraction of NA by RCA.

- Mixture 5 ( $80 \%$ RCA): Asphalt mixture replacing $80 \%$ of $5-13 \mathrm{~mm}$ fraction of NA by RCA.

To establish the OAC all mixes were manufactured with $4.0 \%, 4.5 \%$ and $5 \%$ of asphalt content. After establishing the $\mathrm{OAC}$ of each mixture, tests were performed at $25^{\circ} \mathrm{C}$-water resistance, permanent deformation and modulus of stiffness. Table 3 includes the aggregate proportions of each fraction used in the mixtures.

Figure 2 shows the aggregate size distribution of the mixtures designed. The distribution is continuous and corresponds to a dense mixture with a maximum aggregate size of $25 \mathrm{~mm}$, according to the NC 253 specifications [51]. 
Table 3. Percentage of aggregates used for manufacturing AC.

\begin{tabular}{cccccc}
\hline \multirow{2}{*}{ Aggregate Fraction } & \multicolumn{5}{c}{ Aggregate Percentage (\%) } \\
\cline { 2 - 6 } & $\mathbf{0 \%}$ RCA & $\mathbf{2 0 \%}$ RCA & $\mathbf{4 0 \%}$ RCA & $\mathbf{6 0 \%}$ RCA & $\mathbf{8 0 \%}$ RCA \\
\hline NA (<0.074 $\mathbf{~ m m )}$ & 10 & 10 & 10 & 10 & 10 \\
NA (0-5 $\mathbf{~ m m )}$ & 35 & 35 & 35 & 35 & 35 \\
NA (5-13 $\mathbf{~ m )}$ & 30 & 24 & 18 & 12 & 6 \\
NA (13-25 $\mathbf{~ m m ) ~}$ & 25 & 25 & 25 & 25 & 25 \\
RCA (5-13 $\mathbf{~ m m ) ~}$ & 0 & 6 & 12 & 18 & 24 \\
\hline
\end{tabular}

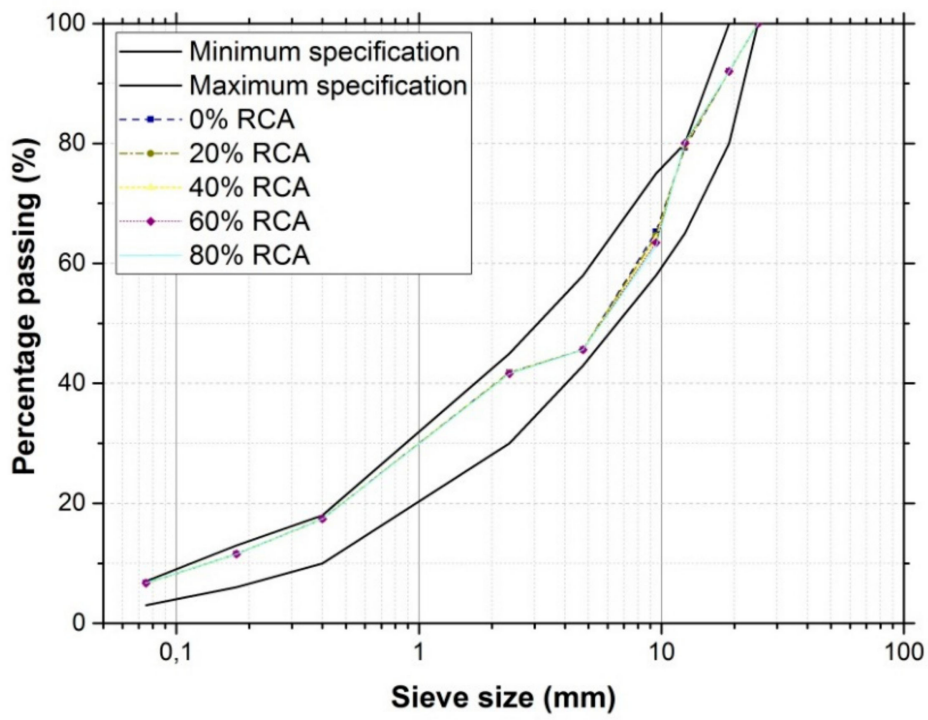

Figure 2. Aggregate size distribution used for the asphalt mixtures. Maximum and minimum values according to NC 253 [51] are also included.

Figure 3 shows the X-ray diffraction (XRD) of the RCA used for AC mixtures. To identify the mineralogical phases, the sample of RCA was reduced in size $(<63 \mathrm{~mm})$ using a Retsch PM 100 model ball mill. The mineralogical phases were determined by XRD using a Bruker D8- Advance diffractometer. The X-ray tube was operated at $40 \mathrm{kV}$ and $40 \mathrm{~mA}$, and the spectra were registered with angles from $4^{\circ}$ to $60^{\circ}$ at $0.05^{\circ}$ stepping intervals. The mineralogical phases of the samples were quantified by Rietveld using the PANalytical Highscore Plus 4.6 software (Malvern Panalytical, Madrid, Spain). In addition, the chemical composition of the RCA was obtained by X-ray fluorescence (XRF) using a sequential spectrometer.

It can be seen (Figure 3) that the main phase detected in the RCA was calcite $(84.2 \%)$ followed by dolomite $(14.9 \%)$-both minerals are identified commonly in concretes whose natural aggregates used in their production are from limestone origin. In addition, Figure 3 shows Portland cement content with $0.9 \%$ Portlandite, which shows the existence of free calcium hydroxide, typical of non-carbonate concretes. It is also noted that the sample of the analyzed residue has a homogeneous chemical composition and does not present any type of contaminant. Table 4 shows the chemical composition of the RCA used, where it can be seen that the predominant chemical compound is calcium, a major element in both the limestone aggregate and the cement paste surrounding the RCA.

Table 4. X-ray fluorescence (XRF) characterization of RCA.

\begin{tabular}{cccccccccccccc}
\hline Oxides & $\mathrm{Na}_{2} \mathbf{O}$ & $\mathbf{M g O}$ & $\mathrm{Al}_{2} \mathrm{O}_{3}$ & $\mathrm{SiO}_{2}$ & $\mathbf{P}_{2} \mathrm{O}_{5}$ & $\mathbf{S O}_{3}$ & $\mathrm{Cl}$ & $\mathbf{K}_{2} \mathrm{O}$ & $\mathrm{CaO}$ & $\mathrm{TiO}_{2}$ & $\mathrm{Fe}_{2} \mathrm{O}_{3}$ & $\mathrm{SrO}$ & $\mathrm{BaO}$ \\
\hline Percentage (\%) & 0.19 & 1.94 & 1.42 & 6.25 & 0.07 & 0.63 & 0.10 & 0.14 & 49.42 & 0.19 & 1.33 & 0.04 & 0.09 \\
\hline
\end{tabular}




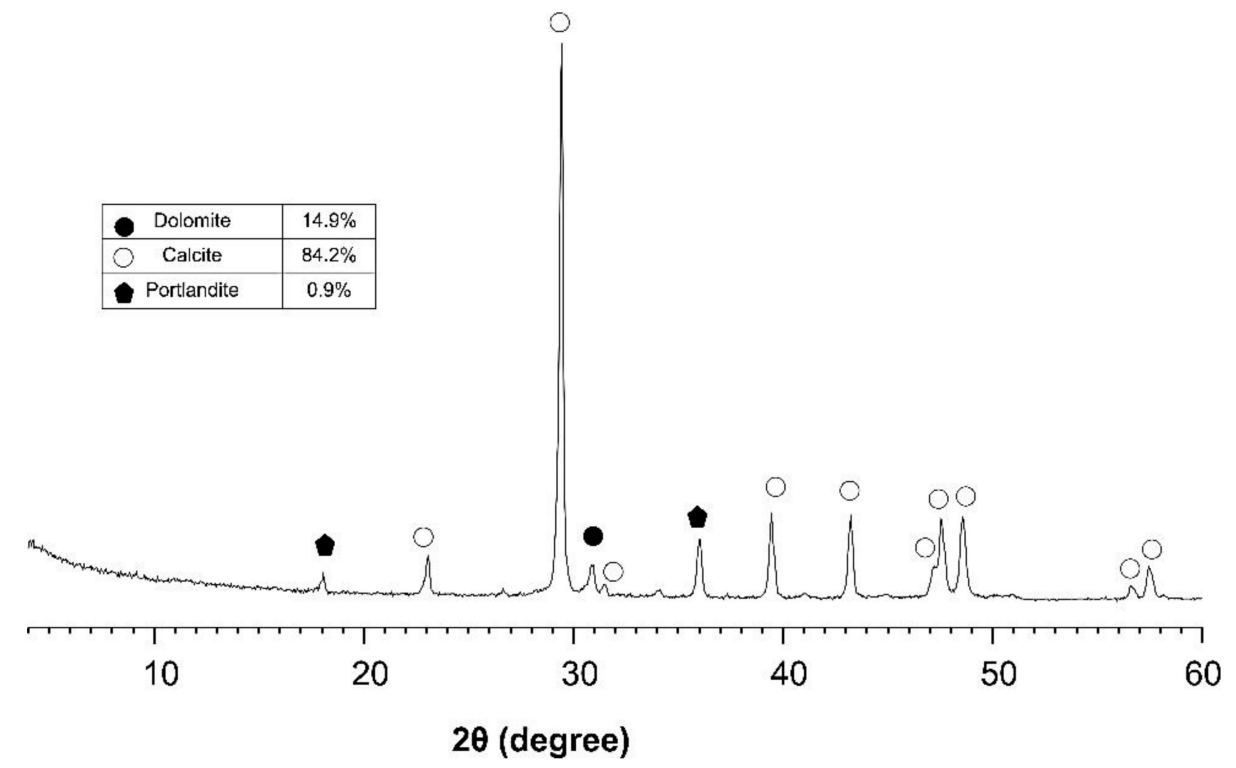

Figure 3. Diffractogram of the RCA used for manufacturing the AC.

The RCA sample was examined with a scanning electron microscope (SEM) (Figure 4) using a Hitachi S3000N. For the morphological analysis, small fragments of the aggregate were obtained and dried in an oven at $60{ }^{\circ} \mathrm{C}$ to avoid altering the sample. Once dry, the small fragments were metallized (30 nm layer) with Au-Pd in Argon atmosphere to increase the quality of the images. The properties of the interfacial transition zone (ITZ) have a significant impact on the macro mechanical properties. As can be seen in Figure 4, these transition zones are subject to fissures, and may affect the mechanical characteristics.
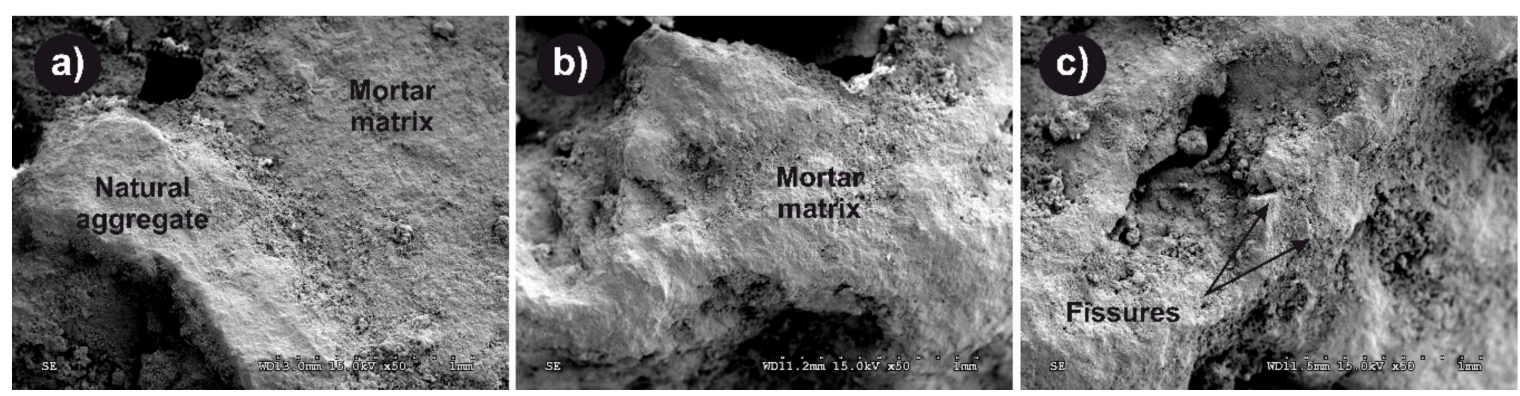

Figure 4. RCA samples images obtained by scanning electronic microscope (SEM) of the RCA acquired at $\times 50$ magnifications. (a) the natural aggregate and the adhered mortar; (b) the RCA morphology; and (c) the RCA fissures.

\subsection{Experimental Methodology}

\subsubsection{Marshall Method}

The properties of the AC mixtures were obtained according the Marshall methodology- NC 261 [50]. The specimens were compacted with 75 strokes per side. Six specimens were manufactured (three for the stability and deformation test and three for obtaining the density and voids) for each percentage of asphalt. The OAC was then established in terms of voids following the specifications proposed by the Spanish Technical Specifications Document (PG-3) [49].

\subsubsection{Water Sensitivity}

For the analysis of the AC water sensitivity, a set of six cylindrical specimens compacted with 50 strokes on each side was manufactured. The set was divided into two subsets of three specimens. 
One subset was kept dry at $25^{\circ} \mathrm{C}$ for $4 \mathrm{~h}$ before testing, while the other was saturated and kept in water at $60^{\circ} \mathrm{C}$ for $24 \mathrm{~h}$ and then at $25^{\circ} \mathrm{C}$ for $4 \mathrm{~h}$ as indicated the NC 253 [51].

After conditioning, the indirect tensile strength of each subset was determined in accordance with EN 12697-23 [52]. The ratio between the indirect tensile strength of the saturated-conditioned subset and that of the dry-conditioned subset expressed as a percentage value (Indirect Tensile Strength Ratio-ITSR) was then determined.

\subsubsection{Stiffness Modulus}

The stiffness modulus was determined in the mixtures with the OAC according to Annex $\mathrm{C}$ (indirect tensile stiffness modulus) of UNE-EN 12697-26 standard [53] on cylindrical specimens. To determine the stiffness modulus of stiffness, the specimens were conditioned at $25^{\circ} \mathrm{C}$ in a temperature-controlled chamber during $24 \mathrm{~h}$ before the test was performed.

The mixtures were compacted with 75 strokes per side. After the specimens were conditioned, five test pulses were applied along the vertical diameter of each cylindrical Marshall specimen. The load had a rise time of $124 \mathrm{~ms}$ and a repetition period of $3 \mathrm{~s}$ equivalent to a frequency of $0.33 \mathrm{~Hz}$. The maximum load applied was selected to produce a maximum horizontal deformation of $0.005 \%$ of the specimen diameter. The test procedure was repeated on a perpendicular diameter. A Poisson coefficient of 0.35 was assumed. The average stiffness of the five test pulses of the two perpendicular diameters tested was recorded as the modulus of stiffness of the AC sample.

\subsubsection{Permanent Deformation}

The permanent deformation measurement was carried according to UNE-EN 12697-22 standard [54]. The samples were prepared according to UNE-EN 12697-33 [55] (dimensions of $300 \times 260 \times 60 \mathrm{~mm}$ compacted using a plate). The samples were conditioned for 16 hours before the test. The test was carried out at a temperature of $60^{\circ} \mathrm{C}$ with a back-and-forth $714 \pm 10 \mathrm{~N}$ loaded wheel (with a $600 \pm 30 \mathrm{kPa}$ pressure) for 10,000 cycles. The permanent deformation was determined according to Equation (1) following the standard [54].

$$
P_{i}=100 \cdot \sum_{j=1}^{15}\left(\frac{m_{i j}-m_{o j}}{15+h}\right)
$$

where $P_{i}$ is the percentage of the rutting depth; $m_{i j}$ is the local deformation in $\mathrm{mm} ; m_{o j}$ is the initial measurement in $\mathrm{mm}$ and $h$ is the thickness of the sample in $\mathrm{mm}$.

\subsubsection{Statistical Analysis}

To statistically determine the significant influence of the different percentages of RCA and asphalt content on the parameters of the mixtures manufactured, the unidirectional and bidirectional analysis of variance (ANOVA) were used. The independent variables were: (i) density; (ii) air voids and voids in the mineral aggregates; (iii) Marshall stability; (iv) Marshall deformation; (v) indirect tensile strength in wet and dry conditions; (vi) stiffness modulus and; (vii) permanent deformation. The study was carried out with a significance level of $5 \%$.

Water sensitivity, stiffness modulus and permanent deformation were measured only for the OAC.

\section{Results and Discussion}

\subsection{Marshall Analysis}

As can be seen in Figure 5, the densities of the mixtures decrease as the percentage of RCA increases, which occurs due to the lower specific weight of recycled aggregates compared to natural aggregates (Table 1). The same behavior was observed in others investigations $[22,24,32,36]$. 
The ANOVA analysis carried out showed that the percentage of recycled aggregate has a significant influence on the density of the mixtures $(p$-value $=0.0023)$ while the percentage of asphalt does not have a significant influence on the density of the mixtures ( $p$-value $=0.156$ ).

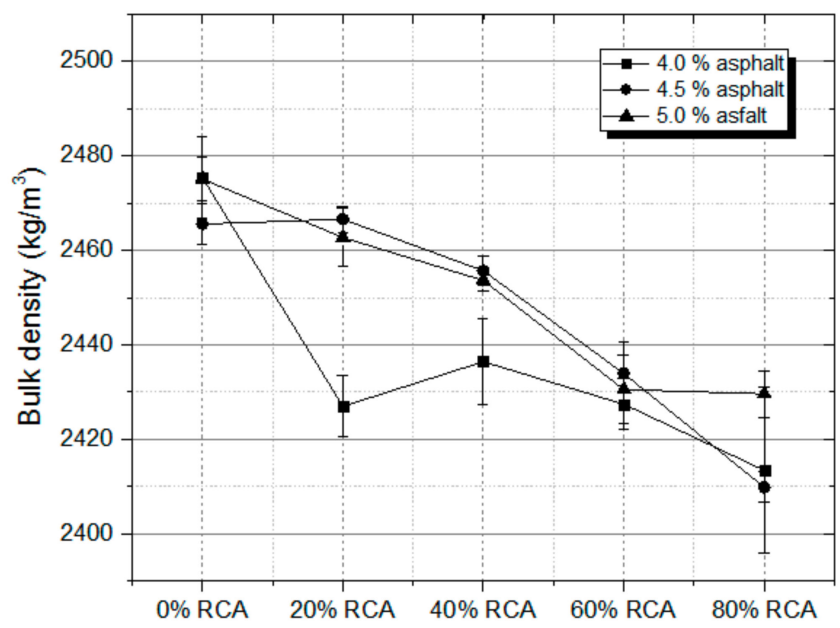

Figure 5. Average bulk density of the bituminous mixtures manufactured with different percentages of RCA and different percentages of asphalt content. The error bars represent the standard deviation.

The voids in the mineral aggregates and the air voids in the mixture increase with the addition of RCA to the AC, as can be seen in Figures 6 and 7, respectively. This variation is due to the high porosity of RCA [22,24]. The ANOVA analysis carried out showed that the percentage of RCA had a significant influence on the voids in the mineral aggregates $(p$-value $=0.015)$ while the asphalt content did not have a significant influence ( $p$-value $=0.282$ ).

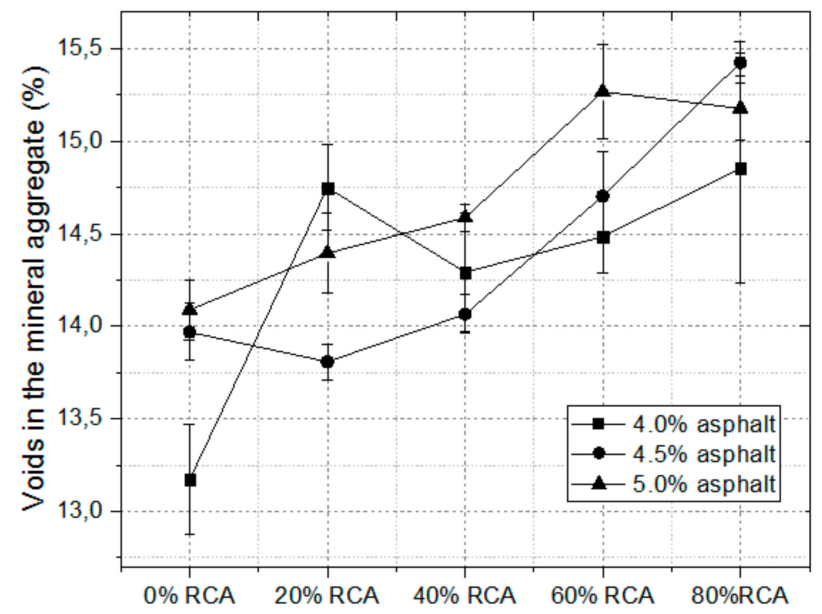

Figure 6. Voids in the mineral aggregate determined in the bituminous mixtures manufactured with different percentages of RCA and different asphalt content. The error bars represent the standard deviation.

As previously mentioned, it can be observed in Figure 7 that, as the percentage of RCA increases, the voids in the mixtures show an ascending behavior. This happens due to the fact that the RA is more porous and has higher absorption than a conventional aggregate. Consequently, there is less asphalt to cover the aggregates because the effective asphalt content at same binder content will be reduced due to the higher absorption and therefore the voids increase as the percentage of RCA increases. In addition, as the asphalt content increase in the mixtures, the air voids in the mixtures decrease due to the fact that the asphalt occupies the volume of the air in the mixture [33]. 
The ANOVA analysis carried out showed that the percentage of recycled concrete aggregate had a significant influence on the air voids $(p$-value $=0.0117)$ as well as the asphalt content $(p$-value $=0.00024)$.

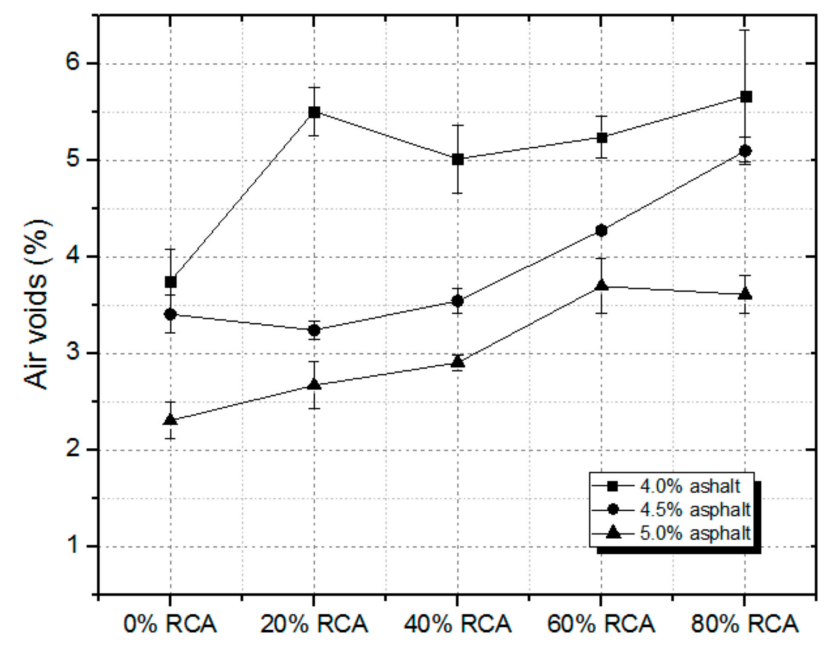

Figure 7. Air voids in the bituminous mixes manufactured with different percentages of RCA and different asphalt content. The error bars represent the standard deviation.

Figure 8 shows that the behavior of the mixtures with different asphalt content were different in terms of Marshall. The mixture with $4 \%$ asphalt content remained stable while for $4.5 \%$ and $5 \%$ asphalt content the stability increased when RCA also increased. In a general, the increase of stability was observed when the RCA content also increased. This behavior was ratified in researches [34,35]. It was also evident that, as the percentage of asphalt content increased, the stabilities of the mixtures decreased due to the deformability that the asphalt provided them.

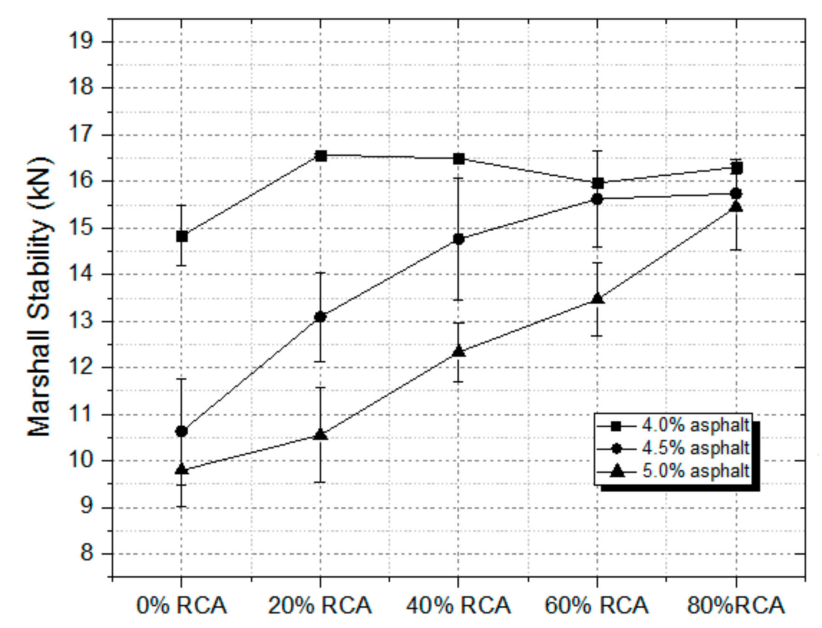

Figure 8. Marshall stability of the bituminous mixtures manufactured with different percentages of RCA and different asphalt content. The error bars represent the standard deviation.

According to the ANOVA analysis carried out, the percentage of RCA did not have a significant influence on the stability of the mix ( $p$-value $=0.062)$ while the percentage of asphalt did have a significant influence on it ( $p$-value $=0.0054)$.

Figure 9 shows that deformation measured decreased when the RCA content increased. This was due to the cement adhering to the RCA and its self-cementing property that makes the mixtures less deformable, as is the case in researches [34,36]. Furthermore, an increase of the mixtures deformations was observed when increased asphalt content because the mixtures was more deformable. 
The ANOVA analysis showed that the RCA and asphalt content had a significant influence on the deformation of the mixture ( $p$-value $=0.00812$ and 0.0013 , respectively).

The optimal asphalt content (OAC) was determined when the volumetric and mechanical properties of the mixtures were analyzed following the Marshall method [50] and the specifications proposed in PG-3 [49].

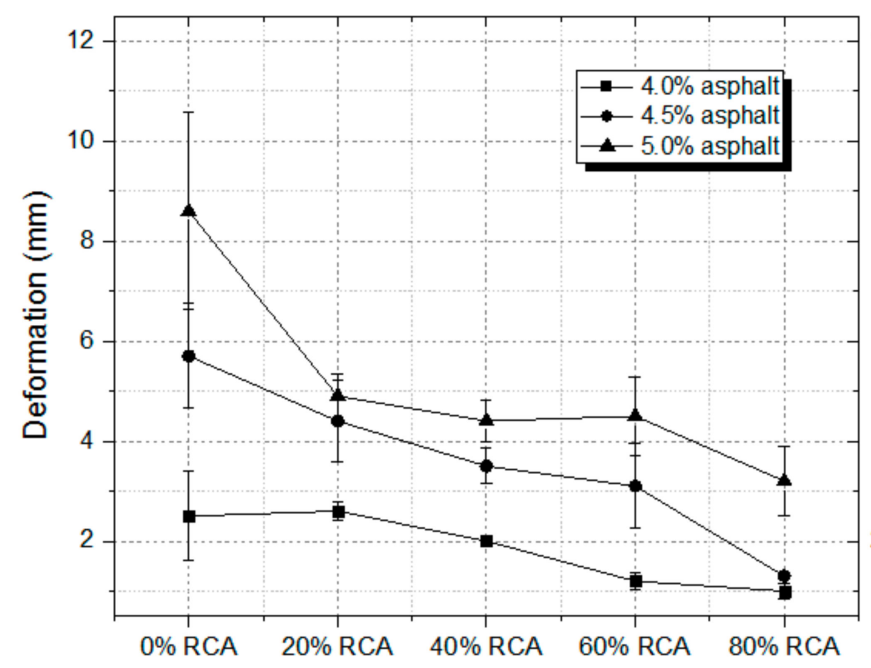

Figure 9. Marshall deformation of the bituminous mixtures manufactured with different percentages of RCA and different asphalt content. The error bars represent the standard deviation.

Figure 10 shows the OAC in the mixtures studied. As can be observed, the OAC increased when the RCA content was higher as a consequence of the higher RCA absorption than the natural aggregate (Table 1). This high absorption is due to the high porosity of the mortar adhering to the original aggregate, as several authors have reported [22,26,36,37]. Furthermore, it can be seen that up to $40 \%$ of RCA content, the increase in the OAC is not as significant as that of mixtures with 60 and $80 \%$ of RCA content.

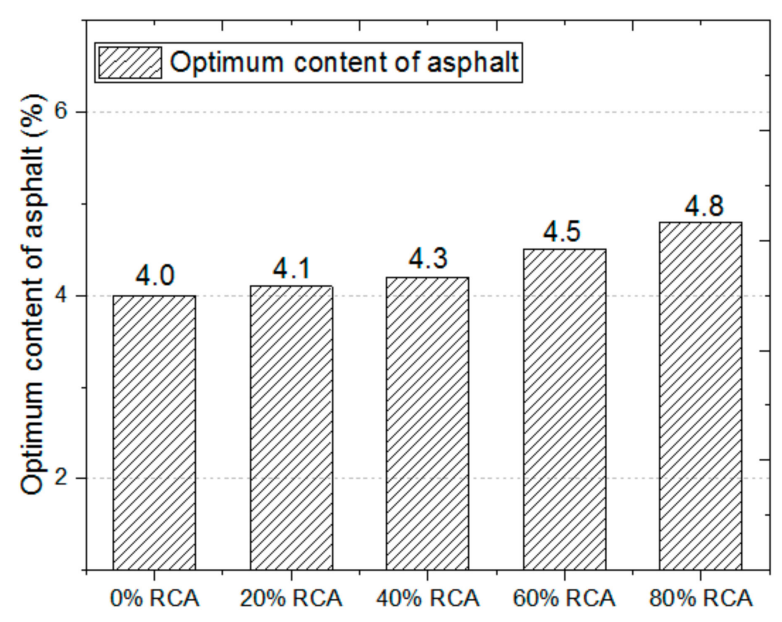

Figure 10. Optimal asphalt content in each mixture studied as indicated the NC 253 [51].

Figure 11 shows the results of the Marshall parameters obtained for mixtures manufactured with the OAC selected as showed Figure 10. As can be observed, the air voids in the mixture (Figure 11b) and the voids in the mineral aggregates (Figure 11c) increased with the content of RCA as a consequence of the reduction in the bulk mixture density (Figure 11a)—as previously mentioned, the RCA is more porous than the NA. 


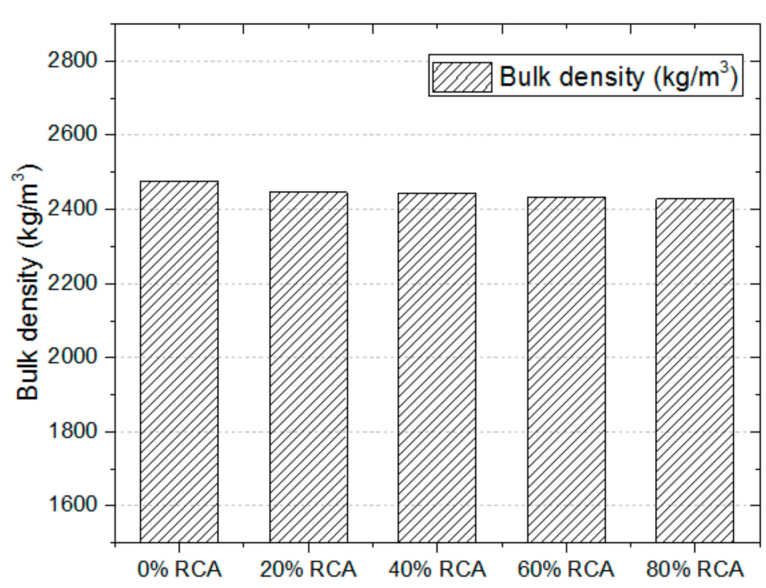

(a)

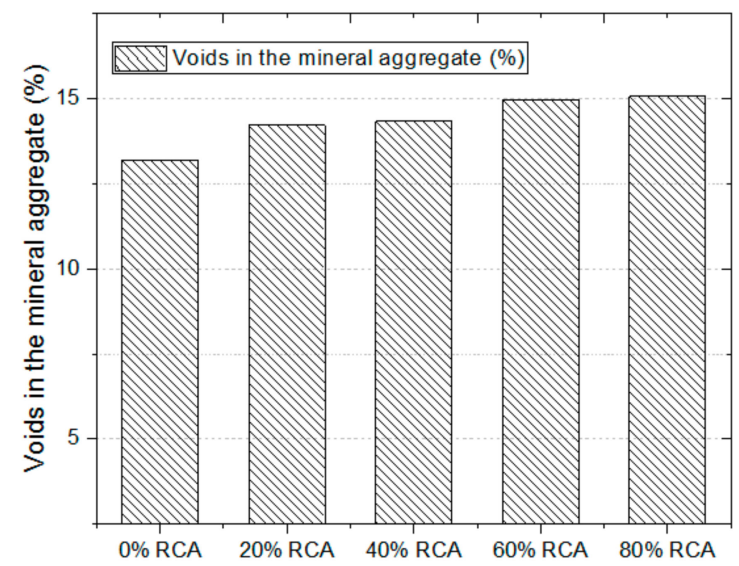

(c)

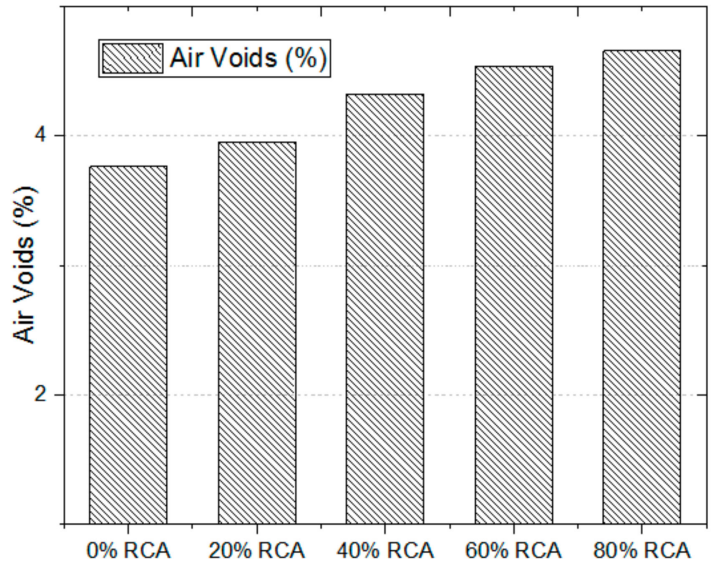

(b)

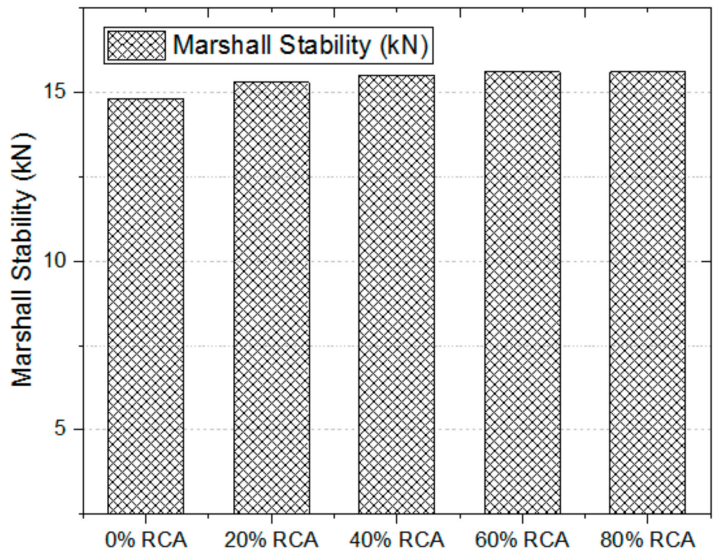

(d)

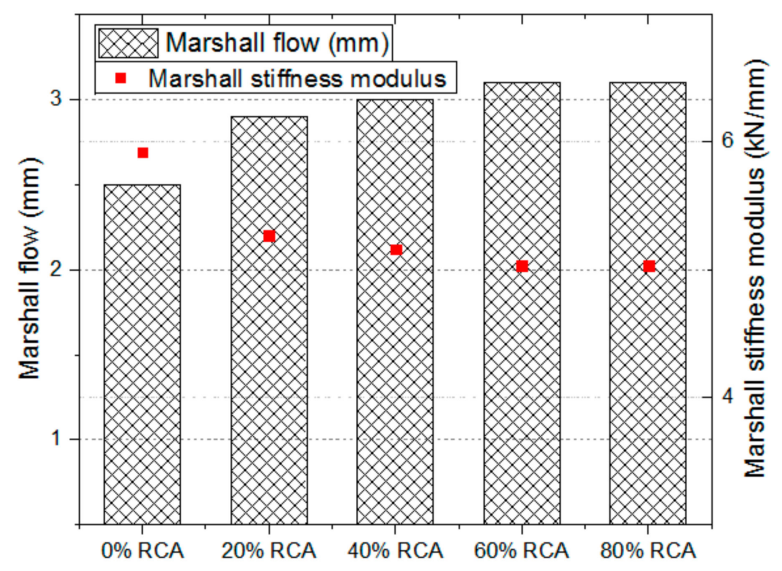

(e)

Figure 11. Marshall parameters for the mixtures manufactured with the optimal asphalt content (OAC). (a) Bulk density of the mixtures; (b) air voids; (c) voids in the mineral aggregates; (d) Marshall stability; and (e) deformation.

It can also be seen that the Marshall stability (Figure 11d) increased with the RCA content. As mentioned, this was due to the self-cementing properties of the RCA. The mortar adhered to the surface provoked an increase in deformations (as can be observed in Figure 11e), because it makes difficult the proper adhesion between the asphalt and the RCA [33] and, as a consequence, provokes less load absorption and therefore an increase of the deformations in the mixtures. 


\subsection{Water Sensitivity}

As can be seen in Figure 12, an increase in the ITSR was determined in the mixtures when RCA content increases in the mixtures manufactured, complying with the technical specifications established in the Spanish recommendations (ITSR $\geq 85 \%$ ) [49]. This behavior is also observed in other research $[37,56]$. The ITSR increase is due to the addition of RCA, which is accompanied by an increase in the OAC as noted previously (Figure 10). As can be seen in Figure 12, there was decrease in the indirect tensile strength when the RCA increased as a consequence of the cement adhering to the original aggregate. The cement attached causes a loss of adhesion between the RCA and the asphalt. However, the indirect tensile strength after immersion increased with the content of RCA up to $40 \%$. This is caused by the contact of the cement attached in the RCA with the water that activates its self-cement properties. The adhesion between RCA and asphalt is not affected in this condition [57]. The indirect tensile strength in wet conditions of the mixtures with $60 \%$ and $80 \%$ of RCA content decreases below the control mixture. This might be due to the instability of these mixtures caused by the RCA abrasion when they were manufactured during the mixing and compaction processes [33].

The ANOVA analysis carried out showed that the percentage of RCA had a significant influence on the indirect tensile strength in dry and wet conditions ( $p$-value $=0.0457$ and 3.23E-14, respectively).

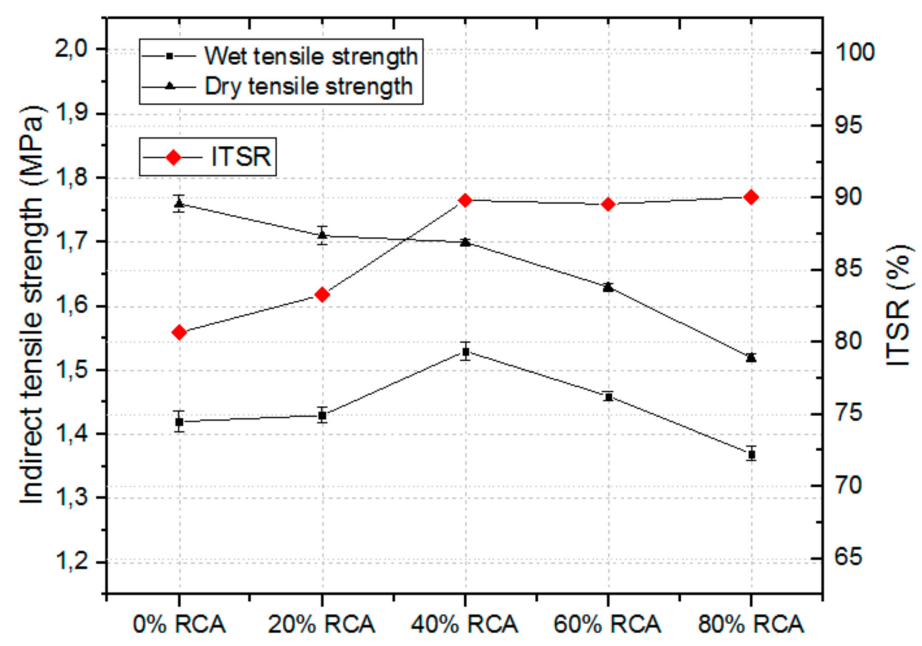

Figure 12. Water sensitivity of mixtures with OAC and different percentages of RCA measured by indirect tensile strength. The error bars represent the standard deviation.

\subsection{Stiffness Modulus}

According the Spanish recommendations, the stiffness modulus of the mixtures should be between 2500 and $8000 \mathrm{MPa}$ at $25^{\circ} \mathrm{C}$ [49]; and according Comunidad Valenciana recommendations [58] it is stated that, for this type of mixture, the stiffness modulus should be between 3500 and $9500 \mathrm{MPa}$. As can be seen in Figure 13, all mixtures met the Spanish recommendation, while only the mixtures with $0 \%, 20 \%$ and $40 \%$ RCA content met the Comunidad Valenciana recommendations. In Figure 13, it is clear that as the percentage of RCA in the mixtures increases, the stiffness modulus of the mixtures decreases, this is attributed to the fragility of the mortar adhering to the RCA, in addition to the increase in the demand for binder (Figure 10) that the mixtures with RCA perceive. The same tendency was observed in the Marshall modulus (Figure 11e) and as has happened in research [24,32]. The same tendency is observed when the load cycles increases as expected [59]. According to ANOVA, the RCA content has a significant influence on the stiffness modulus of the mixture ( $p$-value $=9.4088 \mathrm{E}-8)$. 


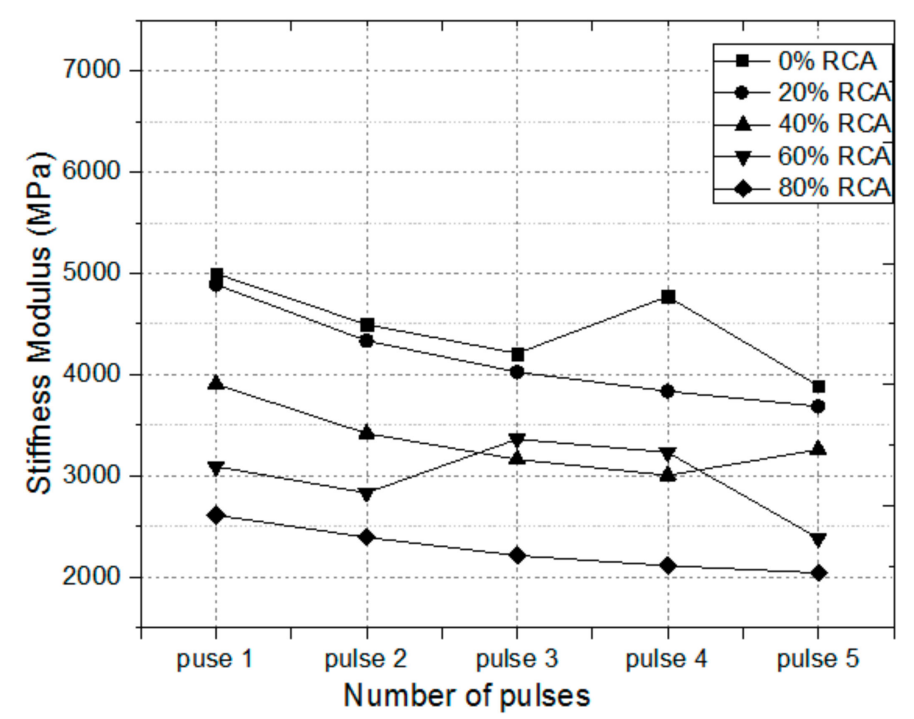

Figure 13. Stiffness modulus, mixtures manufactured with the OAC.

\subsection{Permanent Deformation}

Partial replacement of natural aggregate by RCA does not significantly affect the rutting resistance of asphalt mixtures. As can be observed in Figures 14 and 15, there was a slight reduction of the deformation slope when RCA content increase from $0 \%$ to $40 \%$. The RCA structure and texture, i.e., its rough surfaces and sharp edges (Figure $4 \mathrm{~b}$ ), which are the result of being crushed multiple times, increased the specific surface area and friction between aggregate particles and helped to improve resistance to permanent deformation [4], as reported in scientific literature [31,60]. However, in the mixtures with higher RCA content $(60 \%$ and $80 \%)$, the deformation slope and the rutting depth increased, as reported in [32], probably due to the combined effects of an increased asphalt content and RCA led to a slightly higher permanent deformation, exceeding the limit of $5 \mathrm{~mm}$ recommended in PG-3 [49] and reported in [4].

The ANOVA carried out showed that the percentage of recycled aggregate had a significant influence on the stiffness modulus of the mixtures ( $p$ value $=0.00487$ ).

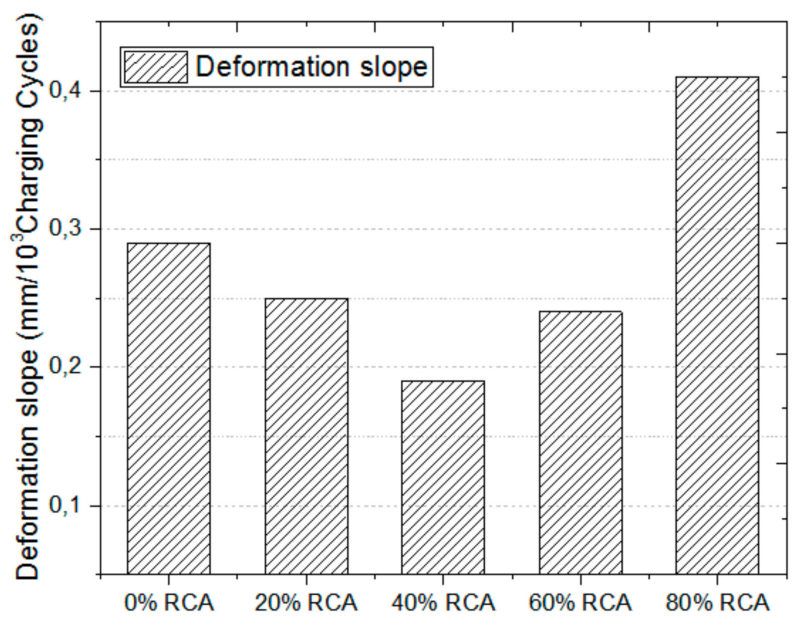

Figure 14. Permanent deformation slope of mixtures manufactured with the OAC. 


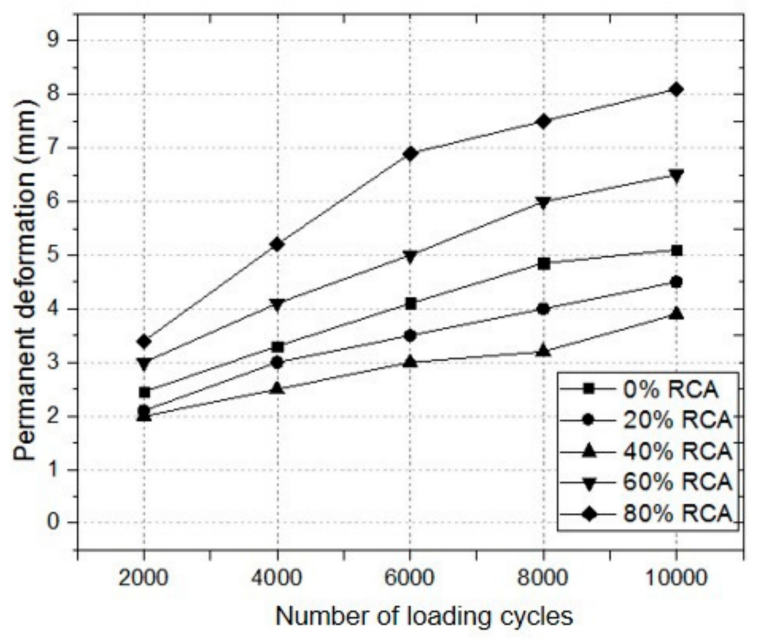

Figure 15. Rutting depth of the mixtures.

\section{Conclusions}

In the present work, hot asphalt concrete mixtures manufactured with recycled aggregate from demolition waste were evaluated. The substitution of $20 \%, 40 \%, 60 \%$ and $80 \%$ of the $5-13 \mathrm{~mm}$ fraction was carried out and the properties of each mixture analyzed with regard to a control mixture (natural aggregate). Based on the results of the laboratory tests and analyses from this study, the following conclusions are summarized:

- As the percentage of recycled concrete aggregates in asphalt mixes increases, volumetric properties such as air voids and voids in the mineral aggregates increase causing a reduction in their bulk densities.

- As the percentage of recycled concrete aggregates in mixtures increases, the demand for bitumen increases.

- The behavior of the mixtures with regard to compression loads and water sensitivity are favored by the incorporation of recycled concrete aggregates only until $40 \%$ of RCA.

- The permanent deformation resistance of mixtures with recycled concrete aggregates meets specifications up to $40 \%$ substitution.

- According to ANOVA, the percentage of recycled aggregate has a significant influence in all the parameters of the mixtures except their Marshall stability.

In spite of finding contradictory values in the scientific literature, which highlights the nonhomogeneity of the RCA compared to natural aggregates, RCA appears to be suitable to use in asphalt concrete. It should be noted that asphalt mixtures manufactured with RCA can meet generally different specifications and they can withstand traffic loads. However, the poor quality of RCA (depending on the source of the material) can affect the engineering properties of the asphalt mixture. This research contributes to demonstrate the suitability of the RCA used as partial replacement of natural aggregates for use in asphalt mixtures.

Author Contributions: Conceptualization, D.A.Á. and A.A.A.; Methodology, D.A.Á., A.A.A. and A.J.T.-A.; Software, D.A.Á., A.A.A. and A.J.T.-A.; Validation, D.A.Á., A.A.A. and A.J.T.-A.; Formal Analysis, D.A.Á., A.A.A. and A.J.T.-A.; Investigation, D.A.Á., A.A.A. and A.J.T.-A.; Resources, D.A.Á.; Data Curation, D.A.Á., A.A.A. and A.J.T.-A.; Writing Original Draft Preparation, D.A.Á.; Writing Review \& Editing, A.A.A. and A.J.T.-A.; Visualization, A.A.A. and A.J.T.-A.; Supervision, A.A.A., A.J.T.-A. and S.I.; Project Administration, S.I.; Funding Acquisition, S.I. All authors have read and agreed to the published version of the manuscript.

Funding: This research was funded by Pavasal Empresa Constructora S.A. and by the University of Alicante (Spain) under grant number [GRE13-03] and [VIGROB-256].

Acknowledgments: We thank Pavasal Empresa Constructora S.A. for assistance some tests and the materials used in the research. 
Conflicts of Interest: The authors declare no conflict of interest.

\section{Nomenclature}

RCA Recycled concrete aggregates

CDW Construction and demolition waste

AC Asphalt concrete

OAC Optimum asphalt content

NA Natural aggregate

\section{References}

1. Torres, R.; Flores, P.; Flores, M.; Flores, V.; Mairon, K. Mezclas asfálticas con materiales reciclados de construcción y demolición para la reparación de pavimentos. In Ciencias Tecnológicas y Agrárias; CECORFAN: Sucre, Bolivia, 2014.

2. Tam, V.W.; Soomro, M.; Jorge, A.C. A review of recycled aggregate in concrete applications (2000-2017). Constr. Build. Mater. 2018, 172, 272-292. [CrossRef]

3. Tenza-Abril, A.J.; Saval, J.M.; Cuenca, A. Using sewage-sludge ash as filler in bituminous mixes. J. Mater. Civ. Eng. 2014, 27. [CrossRef]

4. Radevic, A.; Durekovic, A.; Zakic, D.; Mladenovic, D. Effects of recycled concrete aggregate on stiffness and ruting resistances of asphalt concrete. Constr. Build. Mater. 2017, 136, 386-393. [CrossRef]

5. Tenza-Abril, A.J.; Saval, J.M.; García-Vera, V.E.; Solak, A.M.; Herráiz, T.R.; Ortega, J.M. Effects of Using Mine Tailings from La Unión (Spain) in Hot Bituminous Mixes Desing. App. Sci. 2019, 9, 272. [CrossRef]

6. Taha, R.; Al-Rawas, A.; Al-Jabari, K.; Al-Harthy, A.; Hassan, H.; Al-Oraimi, S. An overview of waste materials recycling in the Sultante of Oman. Resour. Conserv. Recyc. 2004, 41, 293-306. [CrossRef]

7. Tam, V.W.Y.; Tam, C.M. A review on the viable technology for construction waste recycling. Resour. Conserv. Recycl. 2006, 47, 209-221. [CrossRef]

8. Torres, J.R. Study of the Use of Recycled Materials in Road Pavements; Ingeniería de Caminos, Canales y Puertos, Universidad de Cantabria: Cantabria, Spain, 2013.

9. Castelló, J.D. Características de los residuos. In Jornadas Sobre Geotecnia Medioambiental; Proceedings of the Geotecnica Medioambiental: Sevilla, Spain, 2006.

10. Mallick, R.B.; Radzicki, M.J.; Zaumanis, M.; Frank, R. Use of system dymanics for proper conservation and recycling of aggregates for sustinable road construction. Resour. Conserv. Recycl. 2014, 86, 61-73. [CrossRef]

11. Ramonich, E.V.; Barra, M.; Lasalle, L.M.; Canals, F.J.S.; López, I.V.; Pericot, J.R.; Andreu, T.; Balmaceda, A. Aportación de árido Reciclado Mixto con predominio de hormigón para la sutitución de parte del árido fino en la fabricación de mezclas bituminosas. In VII Jornada Nacional de ASEFMA; ASEFMA: Madrid, Spain, 2012; Comunicación 09.

12. Arenal, J.R. Aridos Reciclados industriales: Aplicación en el sector construcción. In Proceedings of the En XV Cursos de Medio Ambiente de Suances. Reciclaje y Sostenibilidad en el sector de la Construcción, Cantabria, Spain, 29 July 2010.

13. Goy, P.J. Estudio Comparativo Entre áridos Reciclados de Residuos de Construcción y Demolición y áridos Comerciales Para Su Uso Como Material Garnular en Sub-base de Carreteras; Facultad de Ciencias Exactas físicas y Naturales, Universidad Nacional de Córdoba: Córdoba, Argentina, 2017.

14. Martínez, J.R.; Vanegas, R.R. Aprovechamiento de Los Residuos de Construcción y Demolición (RCD) Para Ser Utilizados Como Agregados en el Diseño de Mezclas Asfálticas en Caliente; Facultad de Tecnología Politécnica, Universidad Distrital Francisco José de Caldas: Bogotá, Colombia, 2017.

15. Balaguera, A.; Carvajal, G.I.; Albertí, J.; Fullana-i-Palmer, P. Life cycle assessment of road construction alternative materials: A literature review. Resour. Conserv. Recycl. 2018, 132, 37-48. [CrossRef]

16. Topini, D.; Toraldo, E.; Andena, L.; Mariani, E. Use of recycled fillers in bituminuos mixtures for road pavements. Constr. Build. Mater. 2018, 159, 18-197. [CrossRef]

17. Saberian, M.; Li, J.; Nguyen, B.; Wang, G. Permanente deformation behaviour of pavement base and subbase containing recycled concrete aggregate, coarse and fine crumb rubber. Constr. Build. Mater. 2018, 178, 51-58. [CrossRef] 
18. Dyer, P.; Geimba, M.; Klinsky, L.M.; Silva, S.A. Enviromental charcterization of Foundry Waste Sand (WSF) in hot mix asphalt (HMA) mixtures. Constr. Build. Mater. 2018, 171, 474-484. [CrossRef]

19. Sarah, M.A.; Ransinchung, G.D.R.N. Strength and permeation characteristics of cement mortar with Reclaimed Asphalt Pavement Aggregates. Constr. Build. Mater. 2018, 167, 700-706.

20. Singh, S.; Ransinchung, R.N.; Debbarma, S.; Kumar, P. Utilization of reclaimed asphalt pavemenet aggregates conatining waste from Surgarcane Mill for production of concrete mixes. J. Clean. Prod. 2018, 174, 42-52. [CrossRef]

21. Pérez, I.; Rodríguez, A.M. Moisture damage resistance of hot-mix asphalt made with recycled concrete aggregates and crumb rubber. J. Clean. Prod. 2017, 165, 405-414. [CrossRef]

22. Pérez, I.P.; Toledano, M.; Medina, J.G.; Pose, J.T. Mechanical properties of hot mix asphalt made with recycled aggregates from reclaimed construction and demolition debris. Mater. Constr. 2007, 57, 17-29.

23. Muniz, M.; Quiñones, F.; Gómez, A.M.; Ribeiro, M.V.; Farias, P.R. Influence of asphalt rubber on the crushing of recycled aggregates used in dense HMA. In Proceedings of the Asphalt Rubber, Munich, Germany, 23-26 October 2012.

24. Paranavithana, S.; Mohajerani, A. Effects of recycled concrete aggregates on properties of asphalt concrete. Resour. Conserv. Recycl. 2006, 48, 1-12. [CrossRef]

25. Do, H.S.; Mun, P.H.; Keun, R.S. A study on engineering characteristics of asphalt concrete using filler with recycled waste lime. Waste Manag. 2008, 28, 191-199.

26. Wong, Y.D.; Sun, D.D.; Lai, D. Value-added utilisation of recycled concrete in hot-mix asphalt. Waste Manag. 2007, 27, 294-301. [CrossRef]

27. Acosta, D.; Alonso, A.; Tenza-Abril, A.J. Laboratory evaluation of hot asphalt concrete properties with cuban recycled concrete aggregates. Sustainability 2018, 10, 2590. [CrossRef]

28. Acosta, D.; Moll, R.; González, G. Influencia de la utilización del RCD como árido en mezclas asfálticas en caliente. Rev. Arq. Ing. Matan. 2017, 1, 1-14.

29. Liu, Y.; Huang, Y.; Sun, W.; Nair, H.; Lane, D.S.; Wang, L. Effect of coarse aggregate morphology on the mechanical properties of stone matrix asphalt. Constr. Build. Mater. 2017, 152, 48-56. [CrossRef]

30. Fatemi, S.; Imaninasab, R. Performance evaluation of recycled asphalt mixtures by construction and demolition waste materials. Constr. Build. Mater. 2016, 120, 450-456. [CrossRef]

31. Pérez, I.; Toledano, M.; Gallego, J.; Taibo, J. Propiedades mecánicas de mezclas bituminosas en caliente fabricadas con áridos reciclados de residuos de construcción y demolición. Mater. Constr. 2007, 57, 17-29. [CrossRef]

32. Mills-Beale, J.; You, Z. The mechanical properties of asphalt mixtures with Recycled Concrete Aggregates. Constr. Build. Mater. 2010, 24, 230-235. [CrossRef]

33. Rodríguez, A.M. Sensibilidad al Agua y Propiedades Mecánicas de Mezclas Bituminosas en Caliente Fabricadas con áridos; Escuela Técnica Superior de Ingenieros de Caminos, Canales y Puertos, Universidade a Coruña: LA Coruña, Spain, 2013.

34. Arabani, M.; Azarhoosh, A.R. The effect of recycled concrete aggregate and steel slag on the dynamic properties of asphalt mixtures. Constr. Build. Mater. 2012, 35, 1-7. [CrossRef]

35. Sarrag, N.I.A.; Al-Baiti, H.K.A.; Al-Maliky, S.E.S.; Alwan, S.S. Use of Recycling Building Demolition waste As Coarse Aggregate in Hot Mix Asphalt. Tikrit J. Eng. Sci. 2014, 21, 63-76.

36. Pérez, I.; Rodriguez, A.M.; Gallego, J. Hot mix asphalt using C\&D waste as coarse aggregates. Mater. Design. 2012, 36, 840-846.

37. Shen, D.-H.; Du, J.-C. Application of gray Relational Analysis to Evaluate HMA with Reclaimed Building Materials. J. Mater. Civ. Eng. 2005, 17, 400-406. [CrossRef]

38. Conceicao, F.D.; Santos, R.D.; Vasconcelos, K.L.; Bernucci, L. Laboratory evaluation of recycled construcion and demolition waste for pavements. Constr. Build. Mater. 2011, 25, 2972-2979.

39. Bianchini, G.; Marrocchino, E.; Tassinari, R.; Vaccaro, C. Recycling of construction and demolition waste materials: A chemical- mineralogical appraisal. Waste Manag. 2005, 25, 149-159. [CrossRef]

40. Imbachiya, M.C.; Marrocchino, E.; Koilouris, A. Chemical-mineralogical characterisation of coarse recycled concrete aggregate. Waste Manag. 2007, 27, 201-208.

41. Asociación Española de Normalización y Certificación. UNE EN 1097-6/A1. Ensayos Para Determinar las Propiedades Mecánicas y físicas de los áridos. Parte 6: Determinación de la Densidad de las Partículas y la Absorción de Agua; AENOR: Madrid, Spain, 2001. 
42. Asociación Española de Normalización y Certificación. Ensayos Para Determinar las Propiedaes físicas y Mecánicas de los áridos. Parte 2: Métdos Para la Determinación de la Resitencia a la Fragmentación; AENOR: Madrid, Spain, 2007.

43. Asociación Española de Normalización y Certificación. UNE EN 933-3. Ensayos Para Determinar las Propiedades Gemétricas de los áridos. Parte 3: Determinación de la Forma de las Partículas; Índice de Lajas; AENOR: Madrid, Spain, 1997.

44. Asociación Española de Normalización y Certificación. UNE EN 933-8. Ensayos Para Determinar las Propiedades Geométricas de los áridos. Evaluación de los Finos. Ensayo Equivalente de Arena; AENOR: Madrid, Spain, 2000.

45. De Juan, M.S.; Gutiérrez, P.A. Study on the influence of attached mortar content on the properties of recycled concrete aggregate. Constr. Build. Mater. 2009, 23, 872-877. [CrossRef]

46. Asociación Española de Normalización y Certificación. UNE EN 12591. Betunes y Ligantes Bituminosos. Especificaciones de Betunes Para Pavimentación; AENOR: Madrid, Spain, 2000.

47. Asociación Española de Normalización y Certificación. UNE EN 1426. Betunes y Ligantes Bituminosos. Determinación de la Penetración con Aguja; AENOR: Madrid, Spain, 2007.

48. Asociación Española de Normalización y Certificación. UNE EN 1427. Betunes y Ligantes. Determinación del Punto de Reblandecimiento. Método de Anillo y Bola; AENOR: Madrid, Spain, 2007.

49. Ministerio De Fomento. Pliego de Prescripciones Técnicas Generales para Obras de Carretera y Puentes (PG-3) (Statement of General Requirements for Construction of Roads and Bridges (PG-3)); MFOM: Madrid, Spain, 2015.

50. Oficina Nacional de Normalización. NC 261. Determinacion del Contenido óptimo de Asfalto Empleando el Equipo Marshall; Oficina Nacional de Normalización: La Habana, Cuba, 2005.

51. Oficina Nacional de Normalización. Normalización. NC 253. Carreteras. Materiales bituminosos. Hormigón asfáltico caliente. Especificaciones; Oficina Nacional de Normalización: La Habana, Cuba, 2005.

52. Asociación Española de Normalización y Certificación. UNE-EN-12697-12. Método de Ensayo Para Mezclas Bituminosas en Caliente. Determinación de la Sensibilidad Al Agua de las Probetas de Mezcla Bituminosa; AENOR: Madrid, Spain, 2006.

53. Asociación Española de Normalización y Certificación. UNE-EN 12697-26. Mezclas Bituminosas. Métodos de Ensayo Para Mezclas Bituminosas en Caliente. Parte 26: Rigidez; AENOR: Madrid, Spain, 2006.

54. Asociación Española de Normalización y Certificación. UNE EN 12697-22. Mezclas Bituminosas. Método de Ensayo Para Mezclas Bituminosas en Caliente. Ensayo de Rodadura; AENOR: Madrid, Spain, 2008.

55. Asociación Española de Normalización y Certificación. UNE EN 12697-33. Mezclas Bituminosas. Métodos de Ensayo Para Mezclas Bituminosas en Caliente. Elaboración de Probetas con Compactador de Placa; AENOR: Madrid, Spain, 2007.

56. Chen, M.; Lin, J.; Wu, S. Potential of recycled fine aggregates powder as filler in asphalt mixture. Constr. Build. Mater. 2011, 25, 3901-3914. [CrossRef]

57. Poon, C.S.; Chan, D. Feasible use of recycled concrete aggregates and crushed clay brick as unbound road sub-base. Constr. Build. Mater. 2006, 20, 578-585. [CrossRef]

58. Dirección General de obras públicas de la Comunidad Valenciana. Norma de Secciones de Firmes de la Comunidad Valenciana; Conselleria d'Infraestructures i Transport: Valencia, Spain, 2009.

59. Rodriguez, A.M.; Pérez, I. Fatigue performance of bituminous mixture made with recycled concrete aggregates and waste tire rubber. Constr. Build. Mater. 2017, 157, 26-33.

60. Pérez, I.; Rodríguez, A.M. Durbilidad de las mezclas con RCD. In XXVIII Semana de la Carretera; Asociación Española de la Carretera: Santiago de Compostela, Spain, 2010.

(C) 2019 by the authors. Licensee MDPI, Basel, Switzerland. This article is an open access article distributed under the terms and conditions of the Creative Commons Attribution (CC BY) license (http://creativecommons.org/licenses/by/4.0/). 